\title{
Phylogeographic structure in an Australian freshwater shrimp largely pre-dates the geological origins of its landscape
}

\author{
TJ Page and JM Hughes \\ Australian Rivers Institute, Faculty of Environmental Sciences, Griffith University, Nathan, Queensland, Australia
}

\begin{abstract}
The phylogeographic structure of cryptic lineages within the freshwater shrimp Caridina indistincta Calman, 1926 (Decapoda: Atyidae) was investigated in an attempt to unravel any potential genetic influences of Quaternary sea-level oscillations. The study was based on mitochondrial DNA sequences from specimens from lakes and creeks in the sand dune areas of southeast Queensland, eastern Australia. Four divergent lineages were identified, two of which were from Moreton and North (N.) Stradbroke Islands. Lineage ' $\mathrm{C} 1$ ' has been found only on Moreton Island and the western part of N. Stradbroke Island, whereas 'C2' was found on the eastern side of N. Stradbroke Island and a few locations on the mainland. These diverged from each other during the Late Miocene/Pliocene and so are older than the current landscape in which they are found. Small-scale
\end{abstract}

phylogeographic analysis of $\mathrm{C} 1$ identified four separate geographic areas, within the two islands, whose divergences date to the Pleistocene ( 100-300 thousand years ago ('kya')). The N. Stradbroke Island population of C2 also diverged from the mainland during the Pleistocene, as did a sympatric freshwater fish Rhadinocentrus ornatus Regan, 1914 (Melanotaeniidae). This implies that the ice-age sealevel changes may have structured these populations, although there is little observable influence of the last glacial maximum ( $\sim 18 \mathrm{kya})$. Most estimates for the age of the landscape (dunes, lakes) also fall within the Pleistocene and so the effect of sea-level change may be seen both in biology and geology.

Heredity (2007) 98, 222-231. doi:10.1038/sj.hdy.6800932; published online 10 January 2007

Keywords: Caridina; phylogeography; islands; sand dunes; Pleistocene; sea-level change

\section{Introduction}

'To try to understand present-day environments without a knowledge of their history since the last ice age would be like trying to reconstruct the plot of a long novel by reading only the last page.'

SA Elias (1995), The Ice-Age History of Alaskan National Parks (p 4)

The many 'ice ages' of the last million years have had an enormous effect on the physical landscapes of much of the world, evident in terminal moraines, glacial erratics and deep valleys. Even the sunny climes of New Guinea and Australia have hosted glaciers (Frakes et al., 1987). One of the most influential effects of extreme Quaternary climate change was the many oscillations in sea level, with concomitant alterations in coastlines. This reordering of the landscape had significant flow-on effects for the plants and animals that lived within and shows that neither landscape nor biota is static. As the continental shelf drained, new land and dispersal routes

Correspondence: TJ Page, Australian Rivers Institute, Faculty of Environmental Sciences, Griffith University, Nathan, Queensland 4111, Australia.

E-mail: t.page@griffith.edu.au

Received 2 June 2006; revised 30 August 2006; accepted 23

November 2006; published online 10 January 2007 opened up; and as sea levels rose, populations were sundered. This means that the imprint of the ice ages should be evident in genes as well as rocks (Hewitt, 2000).

Continental islands provide an excellent setting in which to study the biological effects of repeated sea-level change because of the intermittent nature of available dispersal routes (Bittkau and Comes, 2005). Southeast Queensland in eastern Australia has four such islands (North Stradbroke, Moreton, Bribie, Fraser) composed almost entirely of sand; the first two of which are in Moreton Bay to the east of Brisbane (Figure 1). The formation of these islands is fascinating in its own right, as their histories, like the rings of a tree, are written in the multiple, sequential sand deposits that formed during various sea-level changes of the Pleistocene (Laycock, 1978; Kelley and Baker, 1984). A combination of prevalent onshore winds from the southeast (Pickett et al., 1985) and changing sea levels (Ward, 1978; Kelley and Baker, 1984) built up a series of sequential and partially overlapped parabolic dunes, each reflecting a specific period of sea-level change (Pickett et al., 1985; Ward, 1985). There are fairly good correlations between dune units on Fraser, Moreton and North (N.) Stradbroke Islands (Ward, 1978; Stock, 1990; Grimes, 1992). The oldest dates obtained for sands at Cooloola (Tejan-Kella et al., 1990) and sediments at Fraser Island (Longmore, 1997) are in the order of 600-730 thousand years ago ('kya'). 


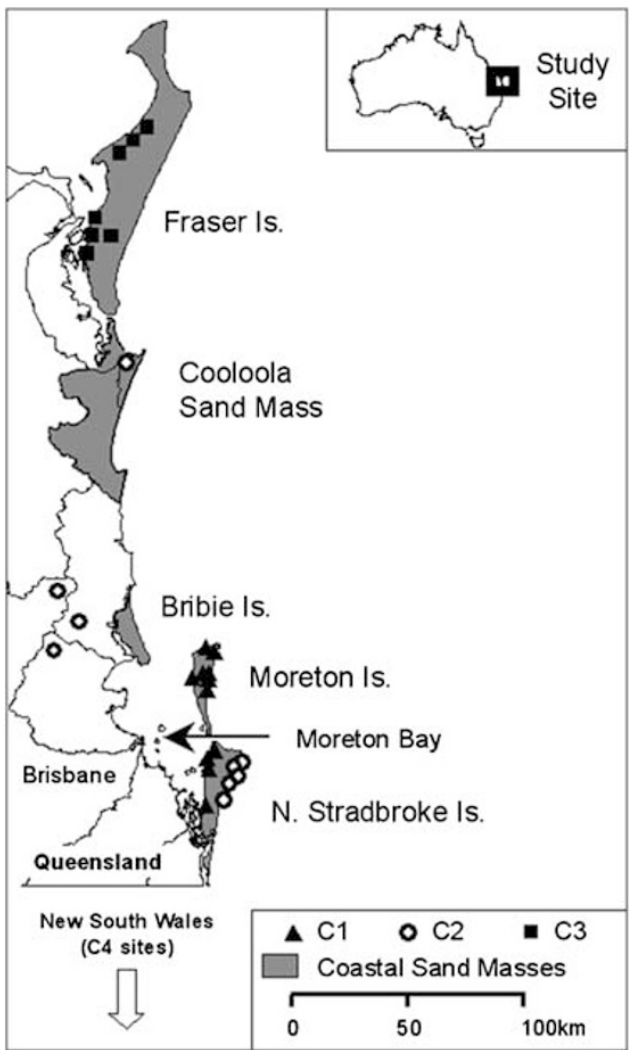

Figure 1 Sampling locations for different $C$. indistincta sp.C lineages $(\mathrm{C} 1, \mathrm{C} 2, \mathrm{C} 3)$ in the sand dune areas of southeast Queensland, eastern Australia (see Table 1 for site details).

Moreton Bay has been a flat, broad plain during much of this time, over which many rivers flowed eastward. These rivers would have gone past large sand dune fields and continued a further $25 \mathrm{~km}$ to the palaeocoastline on the continental shelf (Neal and Stock, 1986). Interglacials occurred roughly every 100000 years (Kershaw et al., 2003). When global climates warmed, the sea came flooding in and Moreton Bay became a 'drowned landscape' (Ward, 1978), isolating the composite dune fields as separate islands (as it appears today).

This area hosts the world's largest sand island (Fraser Island, $1653 \mathrm{~km}^{2}$ ), the highest coastal dune (Mt Tempest, Moreton Island, $280 \mathrm{~m}$ ) and the largest concentration of perched lakes. Despite the sandy substrate, these islands are well vegetated with a mix of environments from lowland coastal heath to rainforest. Low $\mathrm{pH}$ freshwater lakes formed after the dunes stabilised. The water bodies are both 'water table window' lakes and swamps, which are an expression of the groundwater at the surface, and 'perched' lakes, which are set above the regional water table with their own local aquifers.

The dunes on the islands of Moreton Bay that underlie many of water bodies have been characterised as 'Awinya' (Qpa; sensu Ward, 1978) and 'Yankee Jack' (Qpy) (Ward, 1978; Stock, 1990). Pickett et al. (1985) used isotope ratios $\left({ }^{230} \mathrm{Th} /{ }^{234} \mathrm{U}\right)$ to date corals under Awinya sands in northwestern N. Stradbroke Island to $105 \mathrm{kya}$ (revised to 119-132 kya; Tejan-Kella et al., 1990). The 'Yankee Jack' dune unit overlies Awinya and so must be younger (105 kya, Kelley and Baker, 1984; 90 kya, E Stock, personal communication).
Fully freshwater animals from insular environments are excellent model organisms to study the relationship between biota and landscape because of their dispersal limitations due to the lethal nature of intervening dry land or salt water. The freshwater shrimp Caridina indistincta Calman, 1926 (Decapoda: Atyidae) is widespread and common throughout the area, on all of the islands and the mainland. Chenoweth and Hughes (2003) included a few shrimp from Moreton Island in a phylogenetic study and found they represented a cryptic species (Caridina indistincta sp.C). In another phylogenetic study, Page et al. (2005) identified this species from a small number of sites in other sand areas (Cooloola Sand Mass, Fraser and N. Stradbroke Islands) and found it has large eggs, which is indicative of a fully freshwater lifecycle (Hayashi and Hamano, 1984).

A powerful method for inferring biological history, both evolutionary and biogeographic, is the phylogeographic analysis of DNA sequences, and subsequent dating of genetic divergences. This can then be related to current distributions and known geological and geomorphological history to understand their relationships. This has been done effectively with shrimp to investigate effects of Pleistocene climate change in western Queensland and Malaysia (Carini and Hughes, 2004; de Bruyn et al., 2004).

The climate and sea-level changes of the last 18000 years (last glacial maximum, 'LGM') wrought great changes on the landscapes of the world in general and Moreton Bay in particular, with sea levels $150 \mathrm{~m}$ below the present day level, exposing the entire continental shelf and thus providing opportunities for dispersal. This most recent glaciation and the subsequent warming and sea-level rise (17 000-6500 years ago; Neal and Stock, 1986) had significant effects on the intraspecific genetic structuring of many terrestrial and aquatic fauna throughout the world (Hewitt, 2000 and references within), including in the rainforests of Queensland (Schneider et al., 1998).

Barry and Campbell (1977) considered the distribution of various terrestrial vertebrates on N. Stradbroke Island largely determined by the 'land bridge' that existed during the last glacial maximum. Given this suggestion, and the demonstrated effect of the last glacial maximum on the population structures of many taxa around the world, we hypothesise that dispersal opportunities during the LGM should have homogenised the genetic structure of freshwater taxa on these islands, especially given the islands' proximity to the mainland and the fact that they were a part of the mainland until very recently in geological and genetic terms.

A second, alternative, hypothesis is that the LGM, and the Pleistocene itself, did not have the all-encompassing influence that has sometimes been supposed. Interestingly, divergences considerably older than the last glacial maximum and the Pleistocene have also been detected in many populations whose structure had been assumed to have been determined by recent glaciation (Schneider et al., 1998; Hewitt, 2000; Moritz et al., 2000; Bittkau and Comes, 2005).

The two hypotheses of the overriding influence of either the LGM or the Miocene/Pliocene to explain the phylogeographic structure of $C$. indistincta $s p . C$ on the sand islands of Moreton Bay can be tested by relating current distributions, genetic divergences, climate 
history and sand dune ages. Should there be little phylogeographic structure, then the relatively recent LGM was likely most influential. Should the structuring be so deep as to predate the dune landscape, then the Miocene/Pliocene divergences seen in many east Australian freshwater taxa (see Page et al., in press) may also exist within these taxa, even at such small geographic scales.

\section{Materials and methods}

\section{Sampling}

C. indistincta sensu lato were extensively sampled from every basin (135 sites in 36 basins) within an arc of $500 \mathrm{~km}$ emanating from Moreton and N. Stradbroke Islands, with an emphasis on these islands and adjacent mainland areas. Twenty-four sites were sampled on N. Stradbroke Island and nine on Moreton Island, and shrimp were found at nine and seven of these sites, respectively. The other sand dune areas of the region were also sampled (Fraser Island: 21 sites, Bribie Island: nine sites, Cooloola Sand Mass: four sites). Shrimp were caught with seine or dip-nets and preserved in liquid nitrogen or $95 \%$ ethanol.

\section{DNA extraction, polymerase chain reaction and sequencing}

Genomic DNA was extracted and a fragment of the mitochondrial cytochrome oxidase subunit I gene ('COI') was amplified and sequenced as per Page et al. (2005). All specimens were sequenced with the forward primer (CDC0.La; Page et al., 2005) and a third of specimens also with the reverse primer COIa.H (Palumbi et al., 1991).

\section{Construction of data sets}

A total of 426 C. indistincta specimens were sequenced (combined from this study, Chenoweth and Hughes, 2003; Page et al., 2005 and Page and Hughes, unpublished). The only species found on Moreton Island and N. Stradbroke Island was C. indistincta sp.C ('Sp.C') (sensu Chenoweth and Hughes, 2003; Page et al., 2005) and so only this taxon was used for subsequent analyses (150 Sp.C COI sequences of $450 \mathrm{bp}$ ). One hundred and eight of these sequences were generated for this study (new Genbank accession numbers DQ656417-DQ656436) to which were added a further eight and 34 sequences, respectively, from Chenoweth and Hughes (2003) and Page et al. (2005) (Table 1). All 33 unique Sp.C COI haplotypes were included in the COI phylogenetic analyses, with 10 Caridina indistincta sp.A ('Sp.A') haplotypes as an outgroup (some from Fraser/Bribie Islands) (Table 1). A small data set of the more conserved mitochondrial 16S ribosomal DNA ('16S') was also constructed using sequences from Page et al. (2005) and Page et al. (in press) to investigate deeper phylogenetic relationships within Sp.C. The $16 S$ data set of 11 haplotypes of $492 \mathrm{bp}$ was aligned with Sequencher 4.1.2 (Gene Codes Corporation) at default settings (Table 1).

Deep phylogenetic structure was observed within Sp.C, falling into four distinct lineages ('C1', 'C2', 'C3', ' $\mathrm{C} 4$ '); only two of which were found on Moreton and $\mathrm{N}$. Stradbroke Islands (C1, C2). For this reason, data sets for phylogeographic analyses of Moreton and N. Stradbroke
Islands were split into separate sections, namely C1 (72 COI sequences) and C2 (45).

\section{Phylogenetic analyses}

The model of evolution was selected using the Akaike Information Criterion in Modeltest version 3.06 (Posada and Crandall, 1998) for both COI and 16S data sets. Three methods of phylogenetic analyses (tree building) were carried out in PAUP* version 4.0 b10 (Swofford, 2002) for each data set, namely Parsimony Analysis and Maximum Likelihood ('PA'/'ML'; both full heuristic, 100 random repetitions) and Minimum Evolution ('ME'). Each data set was bootstrapped 500 times (PA: full heuristic, 100 random repetitions; ML: 10 random repetitions). TreeRot v.2 (Sorenson, 1999) was used to calculate Bremer Support Values for both PA data sets.

\section{Phylogeographic analyses}

The relationship between local geography on Moreton and N. Stradbroke Islands and small-scale genetic structure within each lineage $(\mathrm{C} 1, \mathrm{C} 2)$ was explored using an analysis of molecular variance (AMOVA; Excoffier et al., 1992) and nested clade analysis (NCA; Templeton et al., 1995). We used Arlequin version 2.0 (Schneider et al., 2000) to partition genetic variation and calculate $\Phi$-statistics given various nested geographical hierarchies in an AMOVA (islands/mainland, between islands, between areas of islands) (10000 permutations for significance testing).

We used NCA to test whether significant associations existed between particular haplotypes and geographic locations, and further to differentiate historical and contemporary processes. A haplotype network was constructed separately for C1 and C2 using TCS version 1.21 (Clement et al., 2000) and the nesting rules of Templeton et al. (1987) and Templeton and Sing (1993) used to assign clades. Geographical locations and haplotype nestings were entered into Geodis version 2.4 (Posada et al., 2000) to test for significant associations, using the November 2005 Inference Key for NCA (available online at: Darwin.uvigo.es/download/ geodisKey_11Nov05.pdf) to infer the most likely biological explanation for the significant clades.

\section{Molecular divergence and clock calculations}

$\mathrm{COI}$ and $16 \mathrm{~S}$ sequence divergences between monophyletic clades were calculated using a distance matrix constructed in PAUP* using the suggested models of molecular evolution including a correction for withinclade polymorphism ( \pm s.e.) (Avise, 1994). Divergence rates used were $1.4 \%$ per million years for COI (Knowlton and Weigt, 1998) and 0.65 and $0.9 \%$ for $16 S$ (Sturmbauer et al., 1996; Schubart et al., 1998). A Likelihood Ratio Test was implemented in PAUP* to test for non-clocklike molecular evolution.

The above method is ineffective in dating divergences between areas that may share haplotypes, so we also used the coalescent method of Nielsen and Wakeley (2001) as implemented in MDIV (Nielsen and Wakeley, 2001; online at: cbsuapps.tc.cornell.edu/mdiv.aspx) to calculate the timing of population divergence $(t)$ and expected timing of most recent common ancestor (tMRCA). We used the following MDIV parameters (model $=$ Finite sites; $[\mathrm{HKY}]$, cycles $=5000000$, burn 
Table 1 Caridina sampling locations and sequences listed by lineage with Genbank accession numbers

\begin{tabular}{|c|c|c|c|c|c|c|c|c|c|}
\hline Lineage & Island/mainland & Part of NSI/MI & Site & Site type $e^{\mathrm{a}}$ & Latitude (S) & Longitude (E) & $\mathrm{N}$ & COI haplotypes $(\mathrm{N})$ & $16 S$ haplotyp \\
\hline \multicolumn{10}{|c|}{ C. indistincta sp. C } \\
\hline \multirow[t]{11}{*}{$\mathrm{C} 1$} & \multirow{7}{*}{ Moreton Is. } & \multirow{2}{*}{ North MI } & Lake Jabiru & WTW & $27^{\circ} 03.16^{\prime}$ & $153^{\circ} 26.14^{\prime}$ & 16 & AY795016(14), DQ656423(1), DQ656426(1) & \\
\hline & & & Spitfire Creek & CK & $27^{\circ} 04.29^{\prime}$ & $153^{\circ} 27.04^{\prime}$ & 4 & AY795016(1), AF155504(3) & AY795044 \\
\hline & & \multirow{5}{*}{ Central MI } & Blue Lagoon Campsite & CK & $27^{\circ} 05.41^{\prime}$ & $153^{\circ} 26.70^{\prime}$ & 2 & DQ656418(1), DQ656422(1) & \\
\hline & & & Blue Lagoon & WTW & $27^{\circ} 05.58^{\prime}$ & $153^{\circ} 26.45^{\prime}$ & 9 & AY795014(6), DQ656421(1), AF155503(2) & \\
\hline & & & Honeyeater Lake ${ }^{b}$ & WTW & $27^{\circ} 05.78^{\prime}$ & $153^{\circ} 26.01^{\prime}$ & 7 & AY795014(7) & DQ478502 \\
\hline & & & Cravens Creek & WTW & $27^{\circ} 06.79^{\prime}$ & $153^{\circ} 22.20^{\prime}$ & 7 & AF155503(7) & \\
\hline & & & Eagers Creek ${ }^{b}$ & CK & $27^{\circ} 09.27^{\prime}$ & $153^{\circ} 25.66^{\prime}$ & 4 & AF155503(4) & \\
\hline & \multirow[t]{4}{*}{ N. Stradbroke Is. } & \multirow[t]{3}{*}{ Northwest NSI } & Aranarawai Creek ${ }^{\mathrm{b}}$ & CK & $27^{\circ} 27.22^{\prime}$ & $153^{\circ} 27.08^{\prime}$ & 5 & AY795014(1), DQ656417(1), DQ656418(3) & \\
\hline & & & Campembah Creek & CK & $27^{\circ} 28.11^{\prime}$ & $153^{\circ} 25.50^{\prime}$ & 1 & AY795015(1) & AY795045 \\
\hline & & & Brown Lake & PL & $27^{\circ} 29.57^{\prime}$ & $153^{\circ} 25.83^{\prime}$ & 7 & AY795014(7) & \\
\hline & & Southwest NSI & Little Canalpin Creek ${ }^{\mathrm{b}}$ & CK & $27^{\circ} 37.35^{\prime}$ & $153^{\circ} 25.15^{\prime}$ & 10 & DQ656419(7), DQ656420(1), DQ656427(2) & \\
\hline \multirow[t]{9}{*}{$\mathrm{C} 2$} & \multirow[t]{5}{*}{ N. Stradbroke Is. } & \multirow[t]{9}{*}{ East NSI } & Keyholes & WTW & $27^{\circ} 29.18^{\prime}$ & $153^{\circ} 30.72^{\prime}$ & 5 & AY795022(5) & \\
\hline & & & Yarraman Lagoon & WTW & $27^{\circ} 29.22^{\prime}$ & $153^{\circ} 30.62^{\prime}$ & 3 & AY795022(3) & \\
\hline & & & 18-Mile Swamp & WTW & $27^{\circ} 31.32^{\prime}$ & $153^{\circ} 29.86^{\prime}$ & 6 & AY795022(6) & \\
\hline & & & Blue Lake ${ }^{\mathrm{b}}$ & WTW & $27^{\circ} 32.06^{\prime}$ & $153^{\circ} 28.86^{\prime}$ & 7 & AY795022(6), AY795023(1) & AY795047 \\
\hline & & & Herring Lagoon & WTW & $27^{\circ} 34.55^{\prime}$ & $153^{\circ} 28.16^{\prime}$ & 9 & AY795022(8), DQ656425(1) & \\
\hline & \multirow[t]{4}{*}{ Mainland North (QLD) } & & Lake Freshwater, Cooloola & PL & $25^{\circ} 59.85^{\prime}$ & $153^{\circ} 08.51^{\prime}$ & 11 & AY795024(11) & \\
\hline & & & Stanley River, Peachester & CK & $26^{\circ} 47.92^{\prime}$ & $152^{\circ} 49.45^{\prime}$ & 1 & AY795021(1) & \\
\hline & & & Coochin Creek $^{\mathrm{b}}$ & CK & $26^{\circ} 51^{\prime}$ & $152^{\circ} 57^{\prime}$ & 1 & DQ656430(1) & \\
\hline & & & North Pine River & CK & $27^{\circ} 07.65^{\prime}$ & $152^{\circ} 44.66^{\prime}$ & 2 & AY795021(2) & AY795046 \\
\hline \multirow[t]{7}{*}{$\mathrm{C} 3$} & \multirow[t]{7}{*}{ Fraser Is. } & & Bowarrady Creek & CK & $25^{\circ} 07.96^{\prime}$ & $153^{\circ} 09.90^{\prime}$ & 2 & DQ656429(1), DQ656432(1) & \\
\hline & & & Woralie Creek & CK & $25^{\circ} 11^{\prime}$ & $153^{\circ} 09^{\prime}$ & 4 & AY795017(1), AY795018(1), DQ656432(2) & \\
\hline & & & Coongul Creek & CK & $25^{\circ} 11.83^{\prime}$ & $153^{\circ} 06.64^{\prime}$ & 2 & DQ656428(1), DQ656432(1) & \\
\hline & & & Wanggoolba Creek & CK & $25^{\circ} 27^{\prime}$ & $152^{\circ} 59^{\prime}$ & 2 & AY795020(2) & \\
\hline & & & Rocky Creek & CK & $25^{\circ} 28.36^{\prime}$ & $153^{\circ} 00.58^{\prime}$ & 5 & AY795019(2), AY795020(3) & DQ478503 \\
\hline & & & Alligator Creek & CK & $25^{\circ} 29.41^{\prime}$ & $152^{\circ} 59.76^{\prime}$ & 2 & AY795019(2) & \\
\hline & & & Lake Birrabeen & PL & $25^{\circ} 30.20^{\prime}$ & $153^{\circ} 02.97^{\prime}$ & 2 & DQ656431(1), AY795019(1) & \\
\hline \multirow[t]{4}{*}{$\mathrm{C} 4$} & \multirow{4}{*}{\multicolumn{2}{|c|}{ Mainland South (NSW) }} & Byron Creek at Binna Burra & CK & $28^{\circ} 42.55^{\prime}$ & $153^{\circ} 29.81^{\prime}$ & 4 & AY795027(4) & AY795049 \\
\hline & & & Nana Creek at Nana Glen & CK & $30^{\circ} 07^{\prime}$ & $153^{\circ} 00^{\prime}$ & 4 & DQ656424(3), AY795025(1) & \\
\hline & & & Bellinger River at Bellingen & CK & $30^{\circ} 27.06^{\prime}$ & $152^{\circ} 53.91^{\prime}$ & 4 & AY795028(4) & AY795050 \\
\hline & & & Kings Creek & CK & $31^{\circ} 31^{\prime}$ & $152^{\circ} 44^{\prime}$ & 2 & AY795026(2) & AY795048 \\
\hline \multicolumn{10}{|c|}{ Outgroup C. indistincta sp. A } \\
\hline \multirow[t]{2}{*}{$\mathrm{A}^{\prime} \mathrm{FI}^{\prime} \mathrm{a}$} & \multirow[t]{2}{*}{ Fraser Is. } & & White Lake & PL & $25^{\circ} 07^{\prime}$ & $153^{\circ} 12$ & 3 & AY794995(3) & \\
\hline & & & Lake Bowarrady & PL & $25^{\circ} 09^{\prime}$ & $153^{\circ} 13^{\prime}$ & 4 & AY794995(4) & \\
\hline \multirow{2}{*}{ A ‘FI'b } & \multirow[t]{2}{*}{ Fraser Is. } & & Lake Allom & PL & $25^{\circ} 11.91^{\prime}$ & $153^{\circ} 12.63^{\prime}$ & 2 & AY794993(2) & \\
\hline & & & Ocean Lake & WTW & $25^{\circ} 30.20^{\prime}$ & $153^{\circ} 02.97^{\prime}$ & 4 & AY794993(2), AY794994(1), DQ656435(1) & DQ478499 \\
\hline \multirow[t]{3}{*}{ A 'GHM' } & \multirow[t]{2}{*}{ Bribie Is. } & & Middle Swamp Crossing ${ }^{\mathrm{b}}$ & WTW & $26^{\circ} 57.76^{\prime}$ & $153^{\circ} 07.65^{\prime}$ & 1 & DQ656434(1) & \\
\hline & & & Williams Creek, Bongaree & CK & $27^{\circ} 05.34^{\prime}$ & $153^{\circ} 09.87^{\prime}$ & 1 & DQ656433(1) & DQ478498 \\
\hline & Mainland North (QLD) & & Coonowrin Creek $^{\mathrm{b}}$ & CK & $26^{\circ} 53.92^{\prime}$ & $152^{\circ} 57.64^{\prime}$ & 1 & AY794997(1) & \\
\hline A 'TCB' & Fraser Is. & & Gerowweea Creek & CK & $25^{\circ} 35.94^{\prime}$ & $153^{\circ} 05.07^{\prime}$ & 3 & AY795000(2), DQ656436(1) & AY795038 \\
\hline & Fraser Is. & & Govi Creek & CK & $25^{\circ} 35.96^{\prime}$ & $153^{\circ} 05.57^{\prime}$ & 1 & DQ656436(1) & \\
\hline & Mainland North (QLD) & & Black Swan Creek & CK & $25^{\circ} 47.84^{\prime}$ & $152^{\circ} 52.26^{\prime}$ & 1 & AF155478(1) & \\
\hline
\end{tabular}

Abbreviations: MI, Moreton Is.; NSI, North Stradbroke Is; QLD, Queensland; NSW, New South Wales.

${ }^{a}$ CK, Creek; PL, Perched Lake; WTW, Water table window lake.

${ }^{\mathrm{b}}$ R. ornatus sequences (this study and Page et al., 2004) from this site. 
in $=10 \%, M_{\max }$ and $T_{\max }=$ various) and converted the highest likelihood value for $T$ (scaled time) and tMRCA into years using the above COI rate as described in Nielsen and Wakeley (2001).

\section{Rhadinocentrus ornatus data set}

A data set of a sympatric freshwater fish, Rhadinocentrus ornatus Regan, 1914 (Melanotaeniidae), was constructed to provide a comparison to the shrimp from this study. Mitochondrial ATPase sequences were obtained from a phylogenetic study (Page et al., 2004). Three new fish specimens were collected and sequenced for the same gene (as per Page et al., 2004) (equals accession number AY452216) from Little Canalpin Creek, N. Stradbroke Island. A haplotype network, NCA, AMOVA and MDIV analyses were carried out on the fish ATPase data set as per the shrimp COI data sets above.

\section{Results}

Phylogenetic and geographical relationships of lineages Four distinct lineages were identified within Sp.C, namely $\mathrm{C} 1, \mathrm{C} 2, \mathrm{C} 3$ and $\mathrm{C} 4$. Both data sets and all analyses support $\mathrm{C} 4$ as a divergent sister group to $\mathrm{C} 1 /$ C2/C3, which form a strong clade (PA COI phylogram; Figure 2) (other bootstrap values, COI ML: 52\%, COI ME: 91\%, 16S PA: 90\%, 16S ML: 86\%, 16S ME: 82\%). The relationship between $\mathrm{C} 1, \mathrm{C} 2$ and $\mathrm{C} 3$ is less clear. They form a polytomy in the COI data set, but the $16 \mathrm{~S}$ analyses (not displayed) supports a clade of C2/C3 (bootstrap values: PA: $89 \%$, ML: $68 \%$, ME: $79 \%$ ).

None of the lineages were found sympatrically. Lineage C4 is not only very phylogenetically divergent but is also geographically distinct, only having been located well to the south of the islands of interest, in mainland coastal basins of the state of New South Wales. Furthermore, C4 has not been found in similar sandy habitats, but largely in subtropical forest.

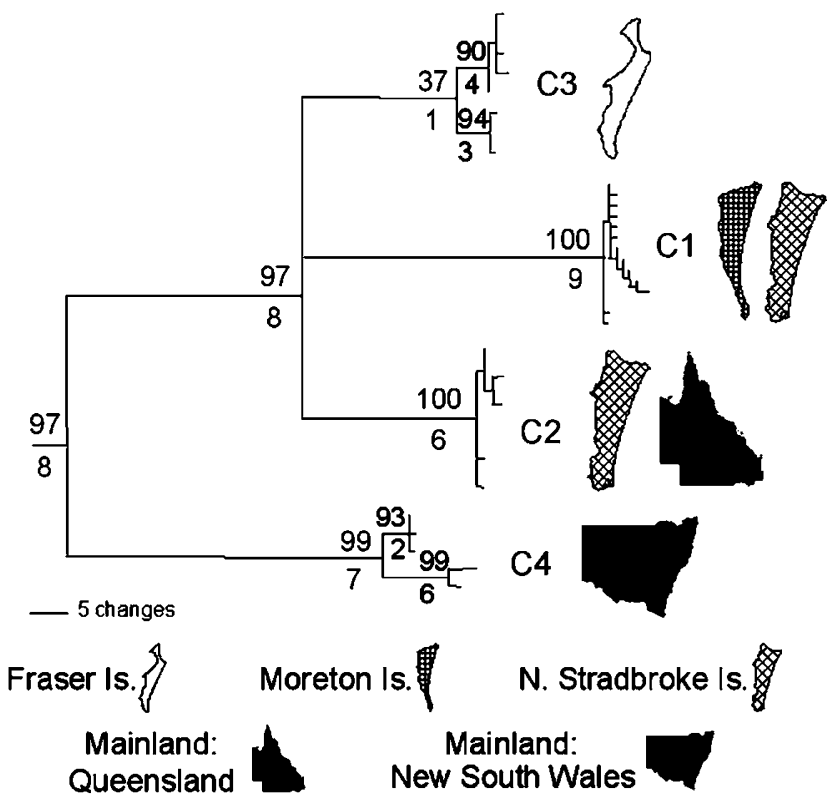

Figure 2 Parsimony phylogram of COI data set, showing specimen geographic location (Bootstrap values above node and Bremer Support values below).
The Moreton Bay islands (N. Stradbroke Island, Moreton Island) are the only known home of C1. It is the only lineage thus far found on Moreton Island, and is also on the western side only of N. Stradbroke Island (Figure 1), but not on the mainland. C2 is also found on N. Stradbroke Island, but only on the eastern side. C2 also exists in disparate populations on the mainland in the state of Queensland (Figure 1), the most significant of which is at Lake Freshwater in the Cooloola Sand Mass. C2 is also found in more rainforest-dominated environments to the south of Cooloola (Figure 1), but these appear to be small populations which are always sympatric with more numerous C. indistincta sp.A ('Sp.A'), which dominate this area. Very few shrimp were found on Bribie Island, and none of these were Sp.C but instead a clade of Sp.A which is common on the nearby mainland.

The final lineage, C3, has only been located on the western side of Fraser Island. There are two geographically distinct clades within C3 (Figure 1). It is unclear whether these represent separate lineages, because the area between them has not been sampled. Fraser is the only island to have both Sp.C and Sp.A (Table 1), including Sp.A 'TCB' (sensu Chenoweth and Hughes, 2003) which is well represented on the nearby mainland.

\section{Divergence between lineages}

All COI and 16S sequence divergences are in Table 2, with C4 notably divergent from the others. The Likelihood Ratio Test could not reject clock-like evolution in either data set (COI: $P=0.0526$; 16 S: $P=0.2527)$. Molecular clock estimates for lineage divergences (Table 2) vary considerably, but most place divergences in the late Miocene/Pliocene. These estimates should be approached with caution because of many potentially confounding factors. In particular, variation in divergence rates between lineages (Cranston and Rannala, 2005). For example, despite the COI data set passing the Likelihood Ratio Test (barely), C1 COI sequences do seem to have diverged more rapidly than the others (Figure 2). This is likely to have an effect on the deeper interlineage COI comparisons involving $\mathrm{C} 1$, but not the more conserved $16 S$ comparisons, nor the shallow intralineage comparisons, where variation between individuals is much less likely. We present the various calculations in Table 2 to place divergences in a broad geological framework, rather than to date them precisely.

\section{Population structure within $\mathrm{C} 1$}

The network of the 14 COI haplotypes found on $\mathrm{N}$. Stradbroke and Moreton Islands (Figure 3) is centred around a common haplotype, which is found on both islands. It is connected by a single mutational step to half of all the haplotypes, and is thus presumably ancestral (Templeton et al., 1987). According to the NCA inference key, 'allopatric fragmentation' explains most of the significant nested clades (Clades 1-3, 1-4, 2-2, Total Cladogram; Figure 3), whereas 'restricted gene flow with isolation by distance' explains Clade 2-1, which corresponds to a linear branch of Moreton Island-only haplotypes.

When Moreton and N. Stradbroke Islands (western side) are defined as geographic groups in an AMOVA, $26.3 \%$ of the variation is partitioned between the islands, 
Table 2 Genetic divergence estimates between and within lineages

\begin{tabular}{|c|c|c|c|c|c|c|c|}
\hline \multirow[t]{2}{*}{ Taxa } & \multicolumn{2}{|c|}{ Sequence divergences } & \multicolumn{2}{|c|}{ Molecular clock (mya) } & \multicolumn{2}{|c|}{ MDIV (mya) } & \multirow[t]{2}{*}{ Entire range (mya) } \\
\hline & $\mathrm{COI}$ & $16 S$ & $\mathrm{COI}$ & $16 S$ & $\mathrm{t}$ & $t M R C A$ & \\
\hline \multicolumn{8}{|l|}{ C. indistincta sp. C } \\
\hline C1,2,3 vs C4 & $18.1 \%(0.3)$ & $3.0 \%(0.2)$ & $12.71-13.08$ & $3.02-4.90$ & 7.03 & 8.52 & $3.02-13.08$ \\
\hline C1 vs C2 & $12.5 \%(0.1)$ & $1.9 \%(0.1)$ & $8.85-8.99$ & $2.03-3.04$ & 4.88 & 5.40 & $2.03-8.99$ \\
\hline C1 vs C3 & $9.6 \%(0.1)$ & $2.6 \%(0.1)$ & $6.76-6.89$ & $2.77-4.23$ & 3.73 & 4.82 & $2.77-6.89$ \\
\hline $\mathrm{C} 2$ vs $\mathrm{C} 3$ & $5.3 \%(0.1)$ & $0.9 \%(0.2)$ & $3.69-3.90$ & $0.72-1.70$ & 2.66 & 3.29 & $0.72-3.90$ \\
\hline C1 NMI vs CMI & $0.6 \%(0.1)$ & & $0.34-0.48$ & & 0.30 & 0.57 & $0.30-0.57$ \\
\hline C1 NWNSI vs SWNSI & $0.2 \%(0.1)$ & & $0.14-0.20$ & & 0.21 & 0.39 & $0.14-0.39$ \\
\hline C1 CMI vs NWNSI & & & & & 0.11 & 0.33 & $0.11-0.33$ \\
\hline C2 ENSI vs Main & $0.3 \%(0.1)$ & $0.4 \%(0.0)$ & $0.13-0.25$ & $0.47-0.65$ & 0.23 & 0.42 & $0.13-0.65$ \\
\hline $\mathrm{C} 3 \mathrm{a}$ vs $\mathrm{C} 3 \mathrm{~b}$ & $2.8 \%(0.1)$ & & $1.90-2.05$ & & 1.32 & 1.74 & $1.32-2.05$ \\
\hline C4a vs $C 4 b$ & $4.1 \%(0.3)$ & $1.1 \%(0.1)$ & $2.77-3.15$ & $1.02-1.83$ & 2.16 & 2.56 & $1.02-3.15$ \\
\hline \multicolumn{8}{|l|}{ R. ornatus } \\
\hline MI/NSI vs Main & & & & & 0.43 & 0.66 & $0.43-0.66$ \\
\hline WNSI vs Main & & & & & 0.35 & 0.66 & $0.35-0.66$ \\
\hline ENSI vs MI & & & & & 0.24 & 0.38 & $0.24-0.38$ \\
\hline Within WNSI & & & & & 0.07 & 0.10 & $0.07-0.10$ \\
\hline
\end{tabular}

Abbreviations: CMI: central MI; ENSI: eastern NSI; Main: mainland Queensland; MI: Moreton Is.; mya: millions of years ago; NMI: northern MI; NSI: North Stradbroke Is.; NWNSI: northwestern NSI; SWNSI: southwestern NSI; $t$ : time of population divergence; tMRCA: time of most recent common ancestor; WNSI: western NSI.

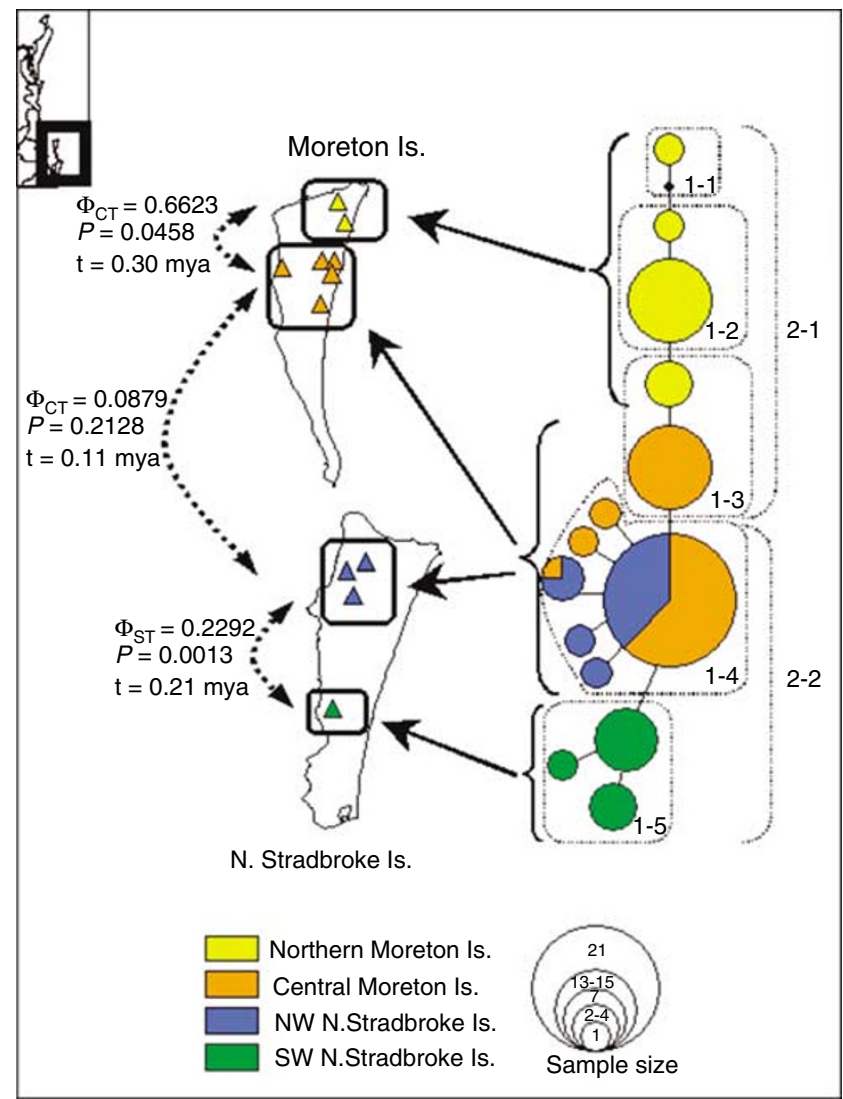

Figure 3 Phylogeography of C. indistincta sp.C1 with haplotype network and NCA clades placed in local geographic context. AMOVA statistics and time since divergence $(t)$ are between adjacent areas ( $\mathrm{mya}=$ million years ago).

but with a non-significant $\Phi_{\mathrm{CT}}(0.263, P=0.1011)$. A reexamination of both the relative geographic locations (Table 1) and the haplotype network (Figure 3) makes it plain that all of the haplotypes from the northern part of
Moreton Island and the southern part of N. Stradbroke Island are unique to their respective distinct areas. In contrast, the areas encompassing the northwest of $\mathrm{N}$. Stradbroke Island and the centre of Moreton Island share haplotypes (including the ancestral one) and only have haplotypes one step from the ancestral. When an AMOVA is carried out with these four areas as the groups (north Moreton Island, central Moreton Island, northwestern N. Stradbroke Island, southwestern N. Stradbroke Island), $62.58 \%$ of the variation is partitioned among them, with a high $\Phi_{\mathrm{CT}}(0.6258)$, which is highly significant $(P=0.0006)$. Separate AMOVAs were also carried out between adjacent areas (north and central Moreton Island: $66.23 \%, \Phi_{\mathrm{CT}}=0.6623, P=0.0458$; central Moreton Island and northwest N. Stradbroke Island: $\left.8.79 \%, \Phi_{\mathrm{CT}}=0.0879, P=0.2128\right)$; northwest and southwest N. Stradbroke Island: $\Phi_{\mathrm{ST}}=0.2292, P=0.0013\left(\Phi_{\mathrm{ST}}\right.$ rather than $\Phi_{\mathrm{CT}}$ because only one site in southwestern $\mathrm{N}$. Stradbroke Island).

These same four groups were used to calculate time since population divergence $(t)$ and time to most recent common ancestor (tMRCA) in MDIV, and all fall within the Pleistocene (Table 2). The split between north and central Moreton Island is the oldest ( $t$ : 0.30 mya, tMRCA: 0.57 ) and between central Moreton Island and north $\mathrm{N}$. Stradbroke Island the most recent ( $t: 0.11$ mya (millions of years ago), tMRCA: 0.33 ).

\section{Population structure within $\mathrm{C} 2$}

The mainland and N. Stradbroke Island (eastern side) share no haplotypes (Figure $4 \mathrm{~b}$ ). Clade $2-1$ (mainland) is either 'allopatric fragmentation' or 'inadequate geographical sampling' depending on whether one assumes there are unsampled shrimp between the observed mainland locations (there probably are, but in low numbers). Therefore, the Total Cladogram (i.e. mainland vs N. Stradbroke Island) suffers the same fate, but 'allopatric fragmentation' is a much more likely explanation given the current presence of Moreton Bay between 
228

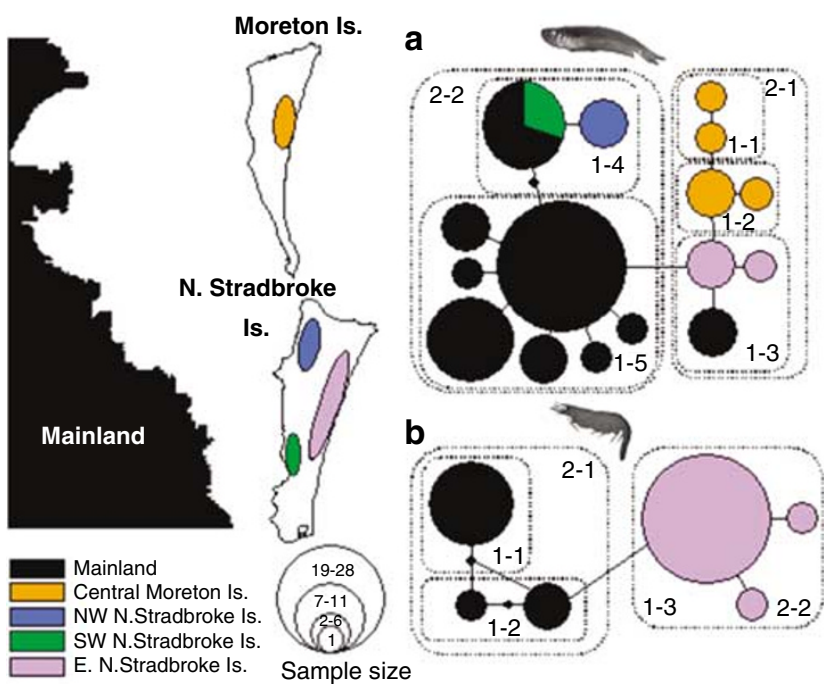

Figure 4 Nested clade analysis (NCA) of (a) R. ornatus and (b) C. indistincta sp.C2 placed in local geographic context.

them, blocking the migration of a freshwater shrimp. The Mainland/N. Stradbroke Island groups explain $80.54 \%$ of the variation in an AMOVA $\left(\Phi_{\mathrm{CT}}=0.80537\right.$, $P=0.0069$ ). MDIV dates the divergence of these groups at 0.23 mya (tMRCA: 0.42 ) (Table 2).

\section{R. ornatus population structure}

Moreton Island fish form a distinct branch (Clades 1-1 and 1-2 in Figure 4a), similar to the shrimp C1 (Clade 2-1 in Figure 3). In contrast, N. Stradbroke Island fish have two separate clades; one from eastern N. Stradbroke Island and related to the Moreton Island clades (1-3, and also containing a mainland haplotype), which NCA explains as "past fragmentation and/or long distance colonization'. The other is from western N. Stradbroke Island (1-4) and is separately derived from the common mainland haplotype. Clades 1-4, 2-1 and the Total Cladogram are considered 'allopatric fragmentation' and Clade 2-2 is 'contiguous range expansion'.

An AMOVA with two groupings of Mainland and Moreton Bay Islands is not significant $\left(\Phi_{\mathrm{CT}}=0.1012\right.$, $P=0.1061$ ), but is just significant with groupings of Mainland, Moreton Island, N. Stradbroke Island $\left(\Phi_{\mathrm{CT}}=0.2457, P=0.0484\right)$, and is highly significant with Mainland, Moreton Island, eastern N. Stradbroke Island, western N. Stradbroke Island $\left(\Phi_{\mathrm{CT}}=0.4076, P=0.0079\right)$. Divergences calculated with MDIV ranged from 0.07 to 0.66 mya (Table 2 ).

\section{Discussion}

\section{The LGM and the Pleistocene}

If the LGM was most influential in the small-scale biogeography of these populations, there should be little genetic structure because of the short times involved ( 18 kya). However, the LGM appears to have had little influence on the population structure of these taxa as there is very limited haplotype sharing, and a great deal of genetic structure at many levels, within and between $\mathrm{C} 1$ and $\mathrm{C} 2$.
The intralineage phylogeographic structure within both $\mathrm{C} 1$ (Figure 3) and C2 (Figure 4b) fall within the Pleistocene (Table 2), but well before the LGM. Comparable patterns in which there is little effect of the most recent ice-age cycle, but significant effects of earlier Pleistocene ice ages ( $\sim 400 \mathrm{kya})$, is also visible in some European taxa (Hewitt, 2000).

Theoretically, biological histories of sympatric taxa should correlate with each other as well as with geological history given a large-scale common geological change ('comparative phylogeography'; Avise, 1994). The sympatric freshwater fish, Rhadinocentrus ornatus, has Pleistocene intraspecific divergences consistent with those within $\mathrm{C} 1 / \mathrm{C} 2$ (Table 2), also considerably predating the LGM. Another sympatric fish, Nannoperca oxleyana, shows low levels of divergence among currently unconnected mainland creeks (Hughes et al., 1999) and thus may display the influence of palaeo-connections during the last glacial maximum. However, Moreton and Fraser Island populations of $N$. oxleyana are distinct and represent isolation from the mainland dating from earlier in the Pleistocene than the LGM.

\section{The Miocene/Pliocene}

Although Pleistocene influence, albeit not the LGM, can be observed in intralineage phylogeographic structure, it cannot account for the deeper between-lineage differences. The genetic divergences between all four Caridina lineages date to the Miocene/Pliocene (Table 2), when many other east Australian freshwater taxa appear to have diverged (Chenoweth and Hughes, 2003; Page et al., 2004; Ponniah and Hughes, 2006; discussed in Page et al., in press). This pattern of unexpected Miocene/Pliocene divergences has also been observed in terrestrial fauna of the wet tropics of Queensland (Schneider et al., 1998; Moritz et al., 2000), the Aegean (Bittkau and Comes, 2005) and elsewhere (Hewitt, 2000).

The $\mathrm{C} 1 / \mathrm{C} 2$ divergence fits in well with large-scale climatic history, as Australia became colder and drier during this time (Frakes et al., 1987). However, this timescale does not equate with the current contact zone between $\mathrm{C} 1$ and $\mathrm{C} 2$, namely the central dunes of $\mathrm{N}$. Stradbroke Island that separate the east and west coasts. The genetic divergence (Table 2) is an order of magnitude older than the ages of the dunes and the water bodies (Table 3), making the shrimp far too old for their current surroundings. A similar situation has been described for stone loach in Lake Constance, as their population subdivision is much older than the lake itself (Barluenga and Meyer, 2005). Plainly these current landscapes cannot explain these levels of differentiation, and we would need to expand our scale in time and space beyond the Pleistocene and Moreton Bay to fully understand this relationship.

\section{Colonisation history of the Moreton Bay Islands}

Given that the intralineage divergences date to the preLGM Pleistocene, we may be able to use the Pleistocene geological history of the area to understand something of the colonisation history of its freshwater fauna. The timing of the formation of the islands, dunes and water bodies is important in unravelling the changing landscape's effect on the genetic structure of its aquatic fauna. 
Table 3 Sand dune unit and approximate ages of sampling site water bodies

\begin{tabular}{|c|c|c|c|c|c|}
\hline Part of island & Site & Caridina lineage & Site type $e^{\mathrm{a}}$ & Dune sand unit ${ }^{\mathrm{b}}$ & Approximate water body age \\
\hline North & Lake Jabiru & $\mathrm{C} 1$ & WTW & Deflated Awinya, encroaching modern & $<90 \pm 10$ kya (sand), $\sim 7.5$ kya (lake) \\
\hline Central & Blue Lagoon & $\mathrm{C} 1$ & WTW & Deflated Awinya, encroaching modern & $<90 \pm 10$ kya (sand), 7.5 kya (lake) \\
\hline \multicolumn{6}{|c|}{ N. Stradbroke Island } \\
\hline Northwest & Brown Lake & $\mathrm{C} 1$ & PL & Reworked Awinya & $<90 \pm 10$ kya \\
\hline Southwest & Little Canalpin Ck. & $\mathrm{C} 1$ & CK & Cooloola dune sand & $>120$ kya \\
\hline East & Blue Lake & $\mathrm{C} 2$ & WTW & Eroded Awinya, encroaching Yankee & $<90 \pm 10$ kya \\
\hline
\end{tabular}

${ }^{\mathrm{a} C K}$, Creek; PL, perched lake; WTW, water table window lake.

${ }^{\mathrm{b}} \mathrm{E}$ Stock (personal communication) using Ward's (1978) units.

${ }^{c}$ Host sand age and lake age by encroaching sand age in kya (thousands of years).

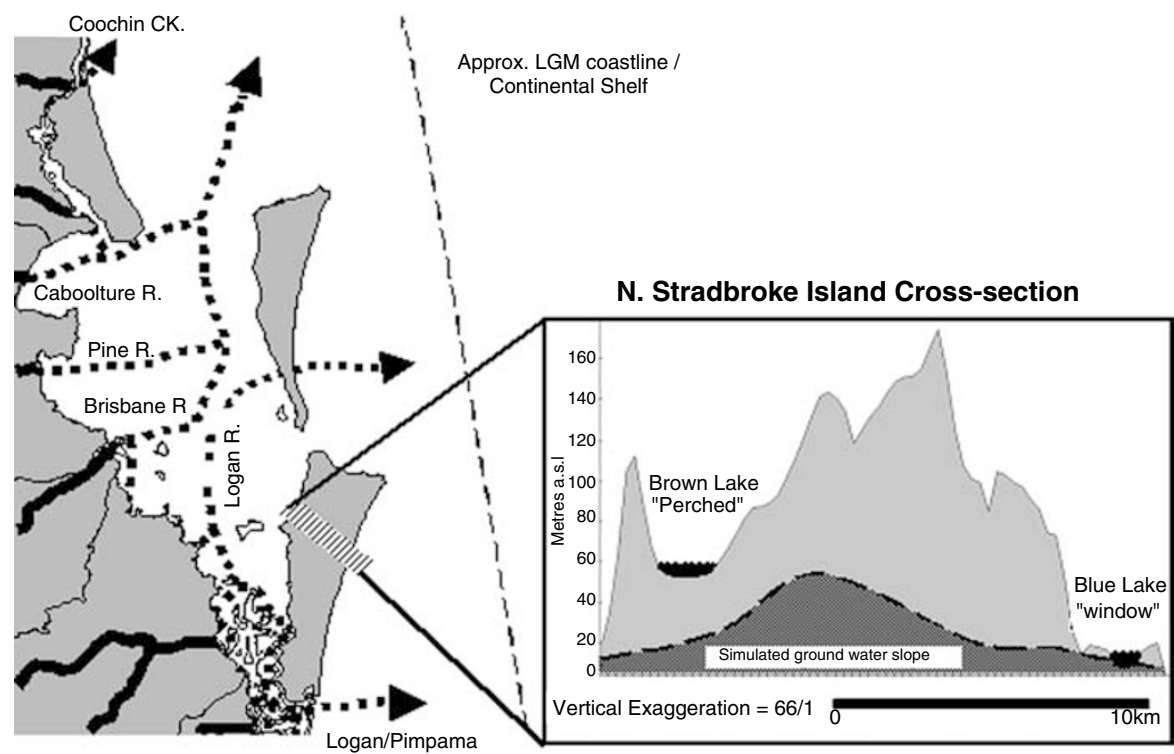

Figure 5 Palaeo-channels of southeast Queensland rivers (Jones, 1992; Lang et al., 1998; Lockhart et al., 1998; E Stock, personal communication), palaeo-coastline (Lang et al., 1998), and cross-section of N. Stradbroke Island. Cross-section created from Dunwich Digital Topographic Data (Code: ANZQL0006000609; ID:5255; Department of Natural Resources, Mines and Water) using Profile Extractor v.6.0.

For our purpose, sand has an advantage over rock as its plasticity makes it more amenable to study at these relatively short time-scales. The precise dating of different dune unit sequences has some of the same inherent uncertainties as for molecular clock dating of DNA sequences referred to above. However, relative ages can be assigned by the stratigraphic relationships of the different dunes and the knowledge of how they formed. For example, because of the direction of prevailing winds, newer dunes tend to form on the eastern ocean side, with older dunes to the west in the centre of the islands (Laycock, 1978).

The divergences within each of the Caridina lineages and Rhadinocentrus fall within the pre-LGM Pleistocene (110-430 kya) and so are consistent with sea-level fluctuations. However, the estimates of genetic divergences (Table 2) and water body ages (Table 3) are not precise enough to correlate with specific glacial/interglacials periods. Interestingly, the population divergences within both Caridina and Rhadinocentrus tend to have a periodicity of about 100 thousand years (C1 divergences: 110, 210, 230, 300 kya; Table 2), which is also the period between major sea-level changes associated with the glacial/interglacial cycle (Kershaw et al., 2003).
This implies that these divergences may have been structured by these major sea-level changes.

More precisely, how could landscape-change foster vicariance or dispersal of Caridina in Moreton Bay? When the plain of Moreton Bay was above sea level, the various rivers which now flow into Moreton Bay (Figure 5) would have continued past the stranded dune fields and may have provided the necessary freshwater connections between water bodies that are isolated during high sea levels (Jones, 1992; Lang et al., 1998; Lockhart et al., 1998). Ironically, a time of cold, arid conditions may have fostered the dispersal of a tropically derived freshwaterobligate shrimp.

This form of past connection may explain why the currently separated central Moreton and northwestern N. Stradbroke Islands are the most similar of the groups within $\mathrm{C} 1$, and how $\mathrm{C} 2$ can have colonised the eastern side of N. Stradbroke Island from the mainland without an opportunity to also colonise the west. An alternative possibility is that when $\mathrm{C} 2$ arrived in eastern $\mathrm{N}$. Stradbroke Island, it outcompeted a previously extant population of $\mathrm{C} 1$. Rhadinocentrus also colonised each side of N. Stradbroke Island independently (Figure 4a) during the Pleistocene, emphasizing the independent colonisa- 
tion history of sympatric taxa, and the independent histories of the two sides of a relatively small island. The large central dunes of N. Stradbroke Island (Figure 5) seem to have kept the different sides of the island isolated for a significant length of time.

If the rivers flowed past these dunes as recently as a few thousand years ago, why should not the Caridina populations be homogenised? Barry and Campbell (1977) point out that a species 'missing' from an island may be due to extinction or to a lack of opportunity to colonise. Obviously, the three dimensional structure of a landscape constrains potential paths of dispersal, especially for an obligately freshwater animal. The vagaries of chance of a river path and intervening dune may have determined whether water bodies were connected during specific glacial periods. The palaeo-channels outlined in Figure 5 may only represent the paths during the LGM and not during previous ice ages (Lang et al., 1998). The aridity and low temperatures (Frakes et al., 1987; Kershaw et al., 2003) associated with these times likely also influenced palaeo-distributions significantly (Ponniah and Hughes, 2006).

Biological and earth histories are intimately connected and both can be reconstructed to tease out the paths they may have taken to arrive at their current positions. The 'legacy' of ice ages (Hewitt, 2000) before the most recent one is likely visible in the intraspecfic genetic structure of freshwater shrimp of Moreton Bay, whereas deep divergences dating from earlier periods of Miocene/ Pliocene climate change are also present. Further interdisciplinary studies utilising both genetic and geomorphological data together should further clarify the complex relationship between landscape and biota in both time and space.

\section{Acknowledgements}

Firstly, we thank Errol Stock of Griffith University for imparting a great deal of knowledge about the sand islands and their formation. Mick Smith (Ecosystem Health Monitoring Project) and Satish Choy (Queensland Department of Natural Resources, Mines and Water) provided some specimens and Satish helped with morphological matters. Andy Morrison (QALSMA) helped us to plan at the beginning. Mariola Hoffman helped with GIS. We thank the following people for help in the field: Kaye Stuart; Ben Cook, James Fawcett, Carl Murray (Griffith University); Jon Marshall, Alisha Steward (QDNRMW); Paul Smith, Scott Whitney (Consolidated Rutile Ltd.); Peter Fugelli (University of Queensland); Gabbi Shuster, Bruce Taylor, Alan Tonks, Annie and Alex Hinde, Daniel and Neil Hay. Funding was provided by the CRC for Freshwater Ecology, Australian Postgraduate Award and Tangalooma Marine \& Research Foundation. Shrimp and fish were sampled under QLD NPWS \& DPI permits.

\section{References}

Avise JC (1994). Molecular Markers, Natural History and Evolution. Chapman \& Hall: New York.

Barluenga M, Meyer A (2005). Old fish in a young lake: stone loach (Pisces: Barbatula barbatula) populations in Lake Constance are genetically isolated by distance. Mol Ecol 14: 1229-1239.
Barry DH, Campbell PR (1977). A survey of the mammals and herptiles of Fraser Island, with comments on the Cooloola Peninsula, N. Stradbroke, Moreton and Bribie Islands. Occ Pap Anthro Uni Qd 8: 147-177.

Bittkau C, Comes HP (2005). Evolutionary processes in a continental island system: molecular phylogeography of the Aegean Nigella arvensis alliance (Ranunculaceae) inferred from chloroplast DNA. Mol Ecol 14: 4065-4083.

Carini G, Hughes JM (2004). Population structure of Macrobrachium australiense (Decapoda: Palaemonidae) in Western Queensland, Australia: the role of contemporary and historical processes. Heredity 93: 350-363.

Chenoweth SF, Hughes JM (2003). Speciation and phylogeography in Caridina indistincta, a complex of freshwater shrimps from Australian heathland streams. Marine Freshwater Res 54: 807-812.

Clement M, Posada D, Crandall KA (2000). TCS: a computer program to estimate gene genealogies. Mol Ecol 9: 1657-1660.

Cranston K, Rannala B (2005). Closing the gap between rocks and clocks. Heredity 94: 461-462.

de Bruyn M, Nugroho E, Mokarrom Hossain MD, Wilson JC, Mather PB (2004). Phylogeographic evidence for the existence of an ancient biogeographic barrier: the Isthmus of Kra Seaway. Heredity 94: 370-378.

Elias SA (1995). The Ice-Age History of Alaskan National Parks. Smithsonian Books: Washington, DC.

Excoffier L, Smouse PE, Quattro JM (1992). Analysis of molecular variance inferred from metric distances among DNA haplotypes: application to human mitochondrial DNA restriction data. Genetics 131: 479-491.

Frakes LA, McGowran B, Bowler JM (1987). Evolution of Australian environments. In: Dyne, GR, Walton, DW (eds). Fauna in Australia. CSIRO: Canberra. pp 1-16.

Grimes KG (1992). Fraser Island, Queensland, 1:250 000 Geological Series - Explanatory Notes. Geological Survey of Queensland: Brisbane.

Hayashi KI, Hamano T (1984). The complete larval development of Caridina japonica (Decapoda, Caridea, Atyidae) reared in the laboratory. Zoo Sci 1: 571-589.

Hewitt G (2000). The genetic legacy of the Quaternary ice ages. Nature 405: 907-913.

Hughes J, Ponniah M, Hurwood D, Chenoweth S, Arthington A (1999). Strong genetic structuring in a habitat specialist, the Oxleyan Pygmy Perch Nannoperca oxleyana. Heredity 83: 5-14.

Jones MR (1992). Moreton Bay and the Sand Islands. In: Wilmott W, Stevens N (eds). Rocks and Landscapes of Brisbane and Ipswich: Geology and Excursions in the Brisbane, Ipswich and Pine River Districts. Geological Society of Australia: Brisbane. pp 27-31.

Kelley RA, Baker J (1984). Geological development of North and South Stradbroke Island and surrounds. In: Coleman RJ, Covacevich J, Davie P (eds). Focus on Stradbroke: New Information on N. Stradbroke Island and Surrounding Areas, 1974-1984. Boolarong Publications: Brisbane. pp 156-166.

Kershaw P, Moss P, Van der Kaars S (2003). Causes and consequences of long-term climatic variability on the Australian continent. Freshwater Biol 48: 1274-1283.

Knowlton N, Weigt LA (1998). New dates and new rates for divergence across the Isthmus of Panama. Proc $R$ Soc Lond $B$ 265: 2257-2263.

Lang SC, McClure ST, Grosser M, Lawless M, Herdy T (1998). Sedimentation and coastal evolution, northern Moreton Bay. In: Tibbetts IR, Hall NJ, Dennison W (eds). Moreton Bay and Catchment. School of Marine Science University of Queensland: Brisbane. pp 81-92.

Laycock JW (1978). N. Stradbroke Island. Pap Dept Geol Uni Qd 8: 89-96.

Lockhart DA, Lang SC, Allen GP (1998). Sedimentation and coastal evolution of southern Moreton Bay. In: Tibbetts IR, Hall NJ, Dennison W (eds). Moreton Bay and Catchment. 
School of Marine Science University of Queensland: Brisbane. pp 93-106.

Longmore ME (1997). Quaternary palynological records from perched lake sediments, Fraser Island, Queensland, Australia: rainforest, forest history and climatic control. Aust J Bot 45: 507-526.

Moritz C, Patton JL, Schneider CJ, Smith TB (2000). Diversification of rainforest faunas: an integrated molecular approach. Annu Rev Ecol Syst 31: 533-563.

Neal R, Stock EC (1986). Pleistocene occupation in the southeast Queensland coastal region. Nature 323: 618-621.

Nielsen R, Wakeley J (2001). Distinguishing migration from isolation: a Markov chain Monte Carlo approach. Genetics 158: 885-896.

Page TJ, Choy SC, Hughes JM (2005). The taxonomic feedback loop: symbiosis of morphology \& molecules. Biol Lett 1: 139-142.

Page TJ, Sharma S, Hughes JM (2004). Deep phylogenetic structure has conservation implications for ornate rainbowfish (Melanotaeniidae: Rhadinocentrus ornatus) in Queensland, eastern Australia. Marine Freshwater Res 55: 165-172.

Page TJ, Zitzler K, Hughes JM (in press). An Island in the stream: Australia's place in the cosmopolitan world of IndoWest Pacific freshwater shrimp (Decapoda: Atyidae: Caridina). Mol Phylogenet Evol (doi:10.1016/j.ympev.2006.08.007).

Palumbi SR, Martin A, Romano S, McMillan WO, Stice L, Grabowski G (1991). A Simple Fool's Guide to PCR. University of Hawaii Press: Honolulu.

Pickett JW, Thompson CH, Kelley RA, Roman D (1985). Evidence of high sea level during isotope stage $5 \mathrm{c}$ in Queensland, Australia. Quat Res 24: 103-114.

Ponniah M, Hughes JM (2006). The evolution of Queensland spiny mountain crayfish of the genus Euastacus. II. Investigating simultaneous vicariance with intraspecific genetic data. Marine Freshwater Res 57: 349-362.

Posada D, Crandall KA (1998). Modeltest: testing the model of DNA substitution. Bioinformatics 14: 817-818.

Posada D, Crandall KA, Templeton AR (2000). GeoDis: a program for the cladistic nested analysis of the geographical distribution of genetic haplotypes. Mol Ecol 9: 487-488.

Schneider CJ, Cunningham M, Moritz C (1998). Comparative phylogeography and the history of endemic vertebrates in the Wet Tropics rainforests of Australia. Mol Ecol 7: 487-498.
Schneider SD, Roessli D, Excoffier L (2000). Arlequin, Version 2.0: Software for Population Genetics and Population Analysis. Genetics and Biometry Laboratory, University of Geneva: Geneva.

Schubart CD, Diesel R, Hedges SB (1998). Rapid evolution to terrestrial life in Jamaican crabs. Nature 393: 363-365.

Sorenson MD (1999). TreeRot Version 2. Boston University: Boston, MA.

Stock EC (1990). Relict parabolic dunes on Moreton Island, Eastern Australia: Structure, formation and provenance. PhD Thesis, Griffith University.

Sturmbauer C, Levinton JS, Christy J (1996). Molecular phylogeny analysis of fiddler crabs: test of the hypothesis of increasing behavioral complexity in evolution. Proc Natl Acad Sci USA 93: 10855-10857.

Swofford DL (2002). PAUP * version 4.065 - Phylogenetic Analysis Using Parsimony (* and Other Methods). Sinauer Associates: Sunderland, MA.

Tejan-Kella MS, Chittleborough DJ, Fitzpatrick RW, Thompson CH, Prescott JR, Hutton JT (1990). Thermoluminescence dating of coastal sand dunes at Cooloola and N Stradbroke Island, Australia. Aust J Soil Res 28: 465-481.

Templeton AR, Boerwinkle E, Sing CF (1987). A cladistic analysis of phenotypic associations with haplotypes inferred from restriction endonuclease mapping I. Basic theory and an analysis of alcohol dehydrogenase activity in Drosophila. Genetics 117: 343-351.

Templeton AR, Routman E, Phillips CA (1995). Separating population structure from population history: a cladistic analysis of the geographical distribution of mitochondrial DNA haplotypes in the tiger salamander, Ambystoma tigrinum. Genetics 140: 767-782.

Templeton AR, Sing CF (1993). A cladistic analysis of phenotypic associations with haplotypes inferred from restriction endonuclease mapping IV. Nested analyses with cladogram uncertainty and recombination. Genetics 134 659-669.

Ward WT (1978). Notes on the origin of Stradbroke Island. Pap Dept Geol Uni Qd 8: 59-66.

Ward WT (1985). Coastal evolution during the last million, the last 10000 , and the last 200 years in southeast Queensland. In: Ward WT (ed). Proceedings of a short course on geological and environmental management, February 1985. Queensland Institute of Technology: Brisbane. pp 172-176. 